\title{
OBLIGASI DAERAH YANG "TAK KUNJUNG" TERBIT SEBAGAI SALAH SATU FAKTOR PERKEMBANGAN DAERAH
}

\author{
Nor Aini ${ }^{1}$, Taymi Triyansyah ${ }^{2}$, \\ Kharis Fadlullah Hana ${ }^{3}$ \\ IAIN Kudus ${ }^{1}$, IAIN Kudus ${ }^{2}$, IAIN Kudus ${ }^{3}$ \\ noraini1021@gmail.com ${ }^{1}$, taymitriyansyah@gmail.com ${ }^{2}$, \\ kharis@iainkudus.ac.id ${ }^{3}$
}

\begin{abstract}
Law No. 33 of 2004 is a source of legal basis used as a guideline in the process of issuing regional bonds. This study discusses issues related to the issuance of regional bonds in Indonesia, particularly in the provinces of Central Java, West Sumatra, and West Kalimantan. In connection with the issuance of regional bonds, to date there are now regions that issue regional bonds including of Central Java, West Sumatra, and West Kalimantan. The purpose of this study is to find out more about the problems that form the basis of the issue of bonds in the region. Researchers use descriptive analysis method that can indicate the level of income and finance of the provinces of Central Java, West Sumatra, West Kalimantan where the region has met the requirements to issue regional bonds. While the SWOT analysis conducted in the area, each region still has many obstacles in the process of issuing regional bonds, one of which is the problem in buman resources (SDM).
\end{abstract}

Keywords: Regional Bonds, Regional Development, SWOT.

\section{Abstrak}

Undang-undang No. 33 tahun 2004 merupakan sumber dasar hukum yang dijadikan pedoman dalam proses penerbitan obligasi daerah. Penelitian ini membahas permasalahan terkait penerbitan obligasi daerah di Indonesia, khususnya pada provinsi Jawa Tengah, Sumatra Barat, dan Kalimantan Barat. Berkaitan dengan penerbitan obligasi daerah, sampai saat ini belum ada daerah yang menerbitkan obligasi daerah termasuk Jawa Tengah, Sumatra Barat, dan Kalimantan Barat. Tujuan dari penelitian ini yaitu untuk mengetahui lebih lanjut permasalahan yang menjadi dasar tidak terbitnya obligasi didaerah tersebut. Peneliti menggunakan metode analisis diskriptif yang dapat menunjukan tingkat pendapatan dan keuangan provinsi Jawa Tengah, Sumatra Barat, Kalimantan Barat dimana daerah tersebut sudah memenuhi syarat untuk melakukan penerbitan obligasi daerah. Sedangkan analisis SWOT yang dilakukan pada daerah tersebut, masing-masing daerah masih memiliki banyak kendala dalam proses penerbitan obligasi daerah salah satunya yaitu permasalahan pada sumber daya manusianya (SDM).

Kata Kunci: Obligasi Daerah, Perkembangan Daerah, SWOT. 


\section{Pendahuluan}

Sejauh ini banyak terjadi masalah mengenai terbatasnya dana di pemerintah daerah sehingga perlu adanya alternatif lain untuk memenuhi kebutuhan dana di pemerintah daerah, salah satunya ialah obligasi daerah. Obligasi daerah merupakan surat utang yang dikeluarkan oleh pemerintah daerah untuk memperoleh pembiayaan (dana) yang bertujuan untuk membiayai daerah yang bersangkutan. Dalam memenuhi kepentingan publik, obligasi daerah dapat digunakan untuk pembiayaan infrastruktur dan juga sarana prasarana pembangunan daerah. Peraturan terkait obligasi daerah telah diterbitkan pada tahun 2000 melalui Peraturan Pemerintah Nomor 107 Tahun 2000 tentang pinjaman daerah (Kementerian Keuangan, n.d.). Namun untuk sekarang ini belum ada pemerintah daerah yang berhasil menerbitkan obligasi daerah, karena mempunyai banyak kendala dalam penerbitan surat hutang atau obligasi daerah tersebut yang bermanfaat untuk mendukung pembiayaan berbagai prospek pembangunan di daerah.

Masalah yang dihadapi pemerintah daerah dalam melaksanakan pembangunan salah satunya adalah berkaitan dengan sumber dana untuk pembiayaan kegiatan yang direncanakan. Bagi pemerintah daerah sumber pembiayaan daerah berasal dari APBN dan PAD, namun tidak jarang sumber utama pembiayaan dari pemerintah masih belum cukup, sehingga daerah harus melaksanakan anggaran defisit dengan meminjam dana dari berbagai sumber dana yang ada. Untuk saat ini pemerintah daerah sedang memunculkan sumber pembiayaan daerah kreatif yaitu obligasi daerah. Namun pemerintah pusat belum berani menerbitkan obligasi daerah, dengan alasan masih banyak daerah yang belum memahami upaya penerbitan obligasi daerah secara komprehensif, sehingga tidak siap melakukan skema pembiayaan. Selain itu SDM di suatu daerah yang ingin menerbitkan masih belum paham mengenai obligasi daerah tersebut serta belum adanya kesiapan dari daerah itu sendiri (News, 2019).

Beberapa penelitian terdahulu yang terkait dengan obligasi daerah sebagai faktor perkembangan daerah, diantaranya Penelitian yang dilakukan oleh Dewi Okta dan David Kaluge yang berjudul "Analisis Peluang Penerbitan Obligasi Daerah Sebagai Alternatif Permbiayaan Daerah" menunjukkan bahwa obligasi daerah dapat digunakan sebagai salah satu sumber pendanaan daerah. Dimana penelitian tersebut bertujuan untuk menganalisis kelayakan penerbitan obligasi daerah sebagai sumber alternatif pembiayaan infrastruktur lokal dan menganalisis strategi yang akan dilaksanakan oleh pemerintah dalam penerbitan obligasi daerah. Alat analisis yang digunakan dalam penelitian ini adalah statistik diskriptif dan analisis SWOT, dimana analisis tersebut dapat menunjukkan bahwa obligasi daerah merupakan alternatif yang layak dipertimbangkan sebagai sumber pendanaan daerah dibanding dengan sumber pendanaan lain (Okta \& Kaluge, 2011).

Selanjutnya penelitian yang dilakukan Ardita Dewi Yulianti yang berjudul "Strategi Penerbitan Obligasi Daerah sebagai Alternatif Sumber Penerimaan 
Daerah di Provinsi Jawa Tengah" pada tahun 2017 mengatakan bahwa provinsi Jawa Tengah telah mampu untuk melakukan penerbitan obligasi daerah dan sudah cakap dalam pemenuhan persyaratan penerbitan obligasi daerah dimana kemandirian keuangan daerah di Jawa Tengah telah mengalami peningkatan, namun Jawa Tengah masih belum mampu menerbitkan obligasi daerah karena belum ada kesiapan terhadap sumber daya manusianya, dimana SDM merupakan aspek terpenting yang dijadikan strategi dalam penerbitan obligasi daerah. Oleh karena itu perlu diadakan peningkatan sumber daya manusia melalui pelatihan pelaporan keuangan sesuai akuntansi pelaporan keuangan pemerintah pusat (Yulianti, 2018).

Dalam penelitian Dian Insani A.W, Edi Suandi H, dan John Supriyanto menunjukan bahwa obligasi daerah dapat memberikan manfaat sebagai sumber alternatif pembiayaan dalam pembangunan BRT di Sulawesi Selatan, dimana dengan adanya pembangunan BRT melalui obligasi daerah akan menciptakan sumber lapangan pekerjaan dan pastinya dapat mengurangi tingkat kemiskinan (Ambarwati et al., 2016).

Penelitian yang telah dilakukan oleh Edi Suandi Hamid dengan judul "Prospek Obligasi Daerah Sebagai Alternatif Pembiayaan Pembangunan" Pada tahun 2003, yang berisi bahwa salah satu sumber pendapatan yang dapat digunakan oleh pemerintah daerah untuk membelanjakan anggaran pembangunan yaitu dengan menjual obligasi daerah. Hal tersebut dimungkinkan setelah pemerintah menerapkan UU No. 22/1999 dan UU No. 25/1999 pada tahun 2001. Meskipun demikian, hingga kini belum ada peraturan pemerintah pusat yang jelas tentang obligasi daerah, namun dimasa depan obligasi daerah dapat berpotensi menjadi sumber pembiayaan pemerintah daerah yang kekurangan dana. Untuk mendukung aksi penjualan obligasi daerah, pemerintah harus membuat unit manajemen utang untuk mengelola obligasi secara lebih profesion (Hamid, 2003).

Kemudian penelitian yang dilakukan Eko Nur Surachman dan Hadi Setiawan yang berjudul "Municipal Bonds as The Financing Strategy for Urban Infrastructure: Case Study of Jakarta MRT" mengatakan tahap II dalam pembangunan MRT menggunakan skema baru yaitu menggunakan obligasi daerah. Dalam penelitian ini menghasilkan bahwa dengan penerbitan obligasi daerah layak untuk sumber pembiayaan dalam pembangunan MRT di Jakarta (Surachman \& Setiawan, 2016).

Penelitian yang dilakukan oleh Wawan Setiadi dengan judul "Kajian Obligasi Daerah Sebagai Alternatif Sumber Pembiayaan Untuk Pembangunan Daerah (Studi Kasus Di Pemerintah Provinsi Jawa Tengah)" yang berisi bahwa Jawa Tengah sebagai studi objek direpresentasikan sebagai daerah yang memiliki kemampuan fiskal yang baik dimana dengan hal tersebut Jawa Tengah termasuk daerah yang kemungkinan sah menerbitkan obligasi daerah. Disisi lain pemerintah Jawa Tengah juga membutuhkan peningkatan pengalaman kemampuan sumber daya manusia mengenai pasar modal, salah satunya prosedur yang mengatur penerbitan obligasi daerah (Setiadi, n.d.). 
Penelitian yang dilakukan oleh Sriyono Sriyono dengan judul "Model Pembiayaan Daerah Yang Bersumber Dari Anggaran Non APBD Untuk Meningkatkan Ekonomi Kreatif" mengatakan bahwa dalam Peraturan No. 33 Tahun 2004, sumber daya keuangan berasal dari pendapatan lokal (PAD), dana perimbangan, area pinjaman, dan penerimaan orang lain adalah sah. Ada beberapa model untuk pembiayaan daerah melalui penerbitan obligasi kota dan memastikan partisipasi komunitas bisnis sebagai bagian dari pemangku kepentingan di daerah untuk terlibat lebih aktif dalam menemukan solusi untuk masalah fiskal daerah tersebut (Sriyono, 2013).

Penelitian yang dilakukan oleh Xingyuan Feng yang berjudul "Local Goverment Debt an Municipal Bonds in China: Problrms and a Framework of Rules" mengatakan bahwa hutang pemerintah daerah di Cina tinggi karena kurangnya dana dari pemerintah pusat. Setelah itu Pusat mengizin kan penerbitan obligasi daerah yang akan menjadi peluang mendapatkan lebih banyak kebutuhan fiskal sehingga dapat mengatasi masalah utang Pemerintah Daerah (Feng, 2013).

Terakhir penelitian menurut Made Gde Subha Karma Resen tentang "Aspek Yuridis Penerbitan Obligasi Daerah sebagai Sumber Pembiayaan Alternatif di Daerab" pemerintah daerah berperan penting dalam kesejahteraan dan pembangunan daerah, namun yang menjadi kendala adalah dana yang diberikan pemerintah pusat tidak cukup, sehingga pemerintah daerah harus mencari dana tambahan dana untuk memperlancar pembangunan dan kesejahteraan daerah. Menerbitkan obligasi daerah merupakan sumber alternatif pendanaan bagi pemerintah daerah untuk merealisasikan di daerah. Serta obligasi daerah menjadi peluang bagi masyarakat di daerah yang menerbitkan untuk berinvestasi (Resen, 2015).

Berbagai penelitian terdahulu yang telah dikemukakan oleh beberapa peneliti diatas, menunjukan hasil bahwa pemerintah daerah di Indonesia masih belum ada yang bisa menerbitkan obligasi daerah. Dikarenakan beberapa hal diantaranya seperti, sumber daya manusia yang masih belum siap untuk mengatur laporan keuangan pemerintah daerah berkaitan dengan obligasi, masih banyak daerah yang belum memahami upaya penerbitan obligasi daerah secara komprehensif sehingga tidak siap melakukan skema pembiayaan obligasi daerah dan juga kurangnya tingkat kesiapan suatu daerah itu sendiri dalam mengatur pelaksanaan obligasi daerah. Pentingnya dalam melakukan penelitian ini ialah peneliti akan mengembangkan pembahasan penerbitan obligasi daerah sebagai faktor perkembangan daerah dimana dengan adanya obligasi daerah dapat membantu keuangan dan segala bentuk infrastruktur yang dibutuhkan daerah sebagai pembangunan daerah. 


\section{Kajian Literatur}

Secara historis, utang kota mendahului utang perusahaan selama beberapa abad di negara Italia. Pada zaman Renaissance awal mula meminjam uang ialah dimulai dari keluarga perbankan utama. Obligasi kota di AS tercatat dimulai sekitar pada tahun 1800. Secara resmi ikatan hutang kota pertama yang dicatat adalah ikatan kewajiban umum yang dikeluarkan oleh Kota New York untuk sebuah kanal pada tahun 1812. Selama tahun 1840-an, banyak kota di AS yang terlilit utang, dan pada tahun 1843 kota-kota memiliki sekitar $\$ 25$ juta hutang. Pada dekade-dekade berikutnya, kota-kota yang terlilit hutang tersebut justru berkembang pesat melalui hutang kota yang diterbitkan. Dimana hutang kota tersebut digunakan untuk membiayai perbaikan perkotaan dan juga bisa memberikan sistem pendidikan publik gratis yang berkembang (Empresas, 2012).

Untuk isu utama atau permasalahan yang muncul dengan adanya desentralisasi fiskal yaitu masalah yang berkaitan dengan kerangka fiskal antara pemerintah dan keuangan publik pemda. Beberapa hal yang menjadi perhatian penting dalam rangka memperkuat kapasitas fiskal daerah yaitu pajak pemerintahan daerah, transfer antar pemerintah, dan pinjaman daerah. Dari berbagai opsi sumber pembiayaan untuk mendukung masalah keterbatasan kapasitas fiskal bagi pemerintah daerah di Indonesia, salah satunya yaitu dengan menerbitkan obligasi daerah (issuing municipal bond).

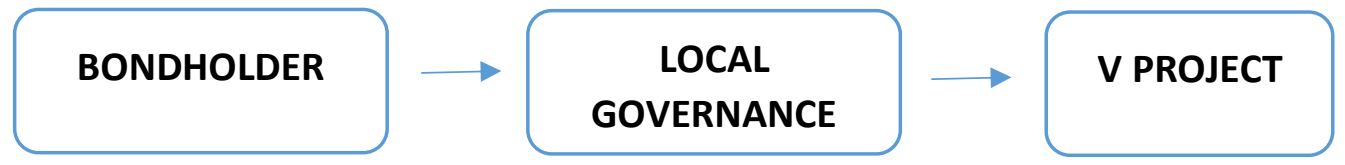

Peraturan Pemerintah Nomor 54 Tahun 2005 tentang Pinjaman Daerah, mengatakan bahwa obligasi daerah yang diterbitkan hanya obligasi pendapatan (revenue bonds). Pada obligasi ini menghasilkan penerimaan karena kegiatan yang dibiayai oleh obligasi daerah harus ada dana yang masuk. Peraturan yang sama juga mengatakan bahwa apabila kegiatan belum menghasilkan dana yang cukup untuk membayar pokok, bunga dan denda maka pembayaran diambil dari APBD (Setiadi, n.d.).

\section{Pengertian Obligasi Daerah}

Obligasi daerah merupakan surat utang yang diterbitkan pemerintah daerah yang ditawarkan kepada publik melalui penawaran umum di pasar modal. Semua risiko yang timbul dari penerbitan obligasi daerah ditanggung oleh pemerintah daerah itu sendiri, karena tidak dilindungi oleh pemerintah pusat, pemerintah pusat hanya memberikan peraturan yang mengatur akan oligasi daerah, untuk risiko yang ditimbulkan dari obligasi daerah ditanggung oleh pemda sendiri. Penerbitan obligasi adalah bukti Pemda telah melakukan pinjaman atau hutang kepada pemegang surat utang. Pemerintah daerah yang 
menerbitkan obligasi daerah memiliki kewajiban untuk membayar bunga secara berkala sesuai dengan jangka waktu yang telah ditetapkan. Obligasi daerah memiliki tujuan untuk membiayai kegiatan terkait investasi pada sektor publik yang menghasilkan penerimaan dan manfaat bagi masyarakat.

\section{Karakteristik Obligasi Daerah}

Obligasi daerah mempunyai karakteristik pinjaman jangka panjang yang berasal dari masyarakat, jangka waktu obligasi yaitu 5 tahun atau lebih, diterbitkan melalui penawaran umum yang diberikan kepada masyarakat melalui pasar modal, obligasi dikeluarkan dalam mata uang rupiah, hasil penjualannya untuk membiayai investasi sektor publik yang menghasilkan dan memberi manfaat bagi masayarakat, dan nilai obligasi saat jatuh tempo sama dengan nilai nominal obligasi pada saat diterbitkan.

\section{Jenis Obligasi Daerah}

Menurut Subiyanto H. obligasi daerah memiliki dua jenis, yaitu:

a. General Obligation Bonds

Obligasi daerah yang diterbitkan untuk membiayai pelayanan publik yang tidak dapat diharapkan pembayarannya melaui fee pada pemakaiannya dan dibayar lagi dengan pajak dan sumber dana lainnya.

b. Revenue Bonds

Obligasi yang diterbitkan untuk proyek yang menghasilkan pendapatan dihari kemudian dan sebagai sumber pembiayaan kembali hutang melalui pemungutan pada pemakainnya seperti, jalan tol, listrik, air minum, pelabuhan.

Menurut Purwoko (2005), berdasarkan perilakunya dan tujuan penggunaan dana yang dihasilkan, obligasi daerah dapat dibedakan menjadi:

a. General Obligation Bond, obligasi yang dikeluarkan oleh pemda untuk mendapatkan dana pembiayaan daerah, yang dapat digunakan sebagai proyek sarana umum yang dibangun oleh pemda dan pengeluaran sehari-hari seperti, jembatan, jalan, tanggul pengendali air, serta fasilitas yang tidak memberikan penghasilan. Kupon dan pengembalian obligasi ini sepenuhnya menjadi beban APBD.

b. Special Revenue Bond, merupakan obligasi yang diterbitkan khusus untuk pembiayaan pembangunan proyek yang menghasilkan pemasukan atau pendapatan, sehingga kupon dan pelunasan obligasi akan dibayar melalui penghasilan dari proyek yang dibangun menggunakan obligasi daerah. Contohnya, pembangunan kawasan pariwisata, dan pembangunan jalan tol.

\section{Kegiatan yang Dapat Dibiayai Obligasi Daerah}

Pemerintah Daerah menerbitkan obligasi daerah digunakan untuk membiayai kegiatan terkait investasi publik yang dikelola oleh pemda berdasarkan peraturan undang-undang yang berlaku dimana obligasi tersebut 
dapat menghasilkan penerimaan dan memberikan manfaat bagi masyarakat di daerah tersebut. Obligasi daerah diterbitkan untuk membiayai beberapa kegiatan yang berbeda. Kegiatan Pemda yang dapat dibiayai dengan obligasi daerah antara lain:
a. Pelayanan air minum
b. Transportasi
c. Rumah sakit
d. Pasar tradisional
e. Tempat perbelanjaan
f. Terminal
g. Tempat wisata
h. Pelabuhan (Okta \& Kaluge, 2011).

\section{Pihak Yang Terkait Dengan Obligasi Daerah}

1. Regulator, merupakan lembaga pemerintahan yang memiliki kewenangan untuk mengatur dan mengawasi pelaksanaan penawaran umum obligasi daerah di pasar modal. Yang bertanggung jawab dalam pengawasan ini adalah Depatermen Keuangan yang dilakukan oleh Bapepam LK dan Direktorat Jendral Perimbangan Keuangan.

2. Self Regulatory Organizations (SRO), adalah lembaga yang bertugas untuk mengeluarkan peraturan bagi kegiatan usaha. SRO terdiri dari bursa efek, lembaga kliring dan peminjaman, dan lembaga penyimpanan dan penyelesaian.

3. Emiten, merupakan pihak yang melakukan penawaran.

4. Pemegang Efek, merupakan investor atau orang yang menanamkan modalnya dalam bentuk pemberian pinjaman kepada pemerintah daerah dalam bentuk obligasi daerah.

5. Perusahaan Efek, merupakan perusahaan yang mempunyai aktivitas sebagai penjamin emisi efek, manajer investasi, perantara pedagang efek, atau gabungan dari ketiga tersebut.

6. Lembaga Penunjang, pihak penunjang terlaksananya pelaksanaan penawaran umum., terdiri dari biro administrasi efek custodian dan wali amanat.

7. Profesi Penunjang, pihak yang turut menunjang terlaksananya penawaran umum di pasar modal.

8. Pihak lain yang terlibat, pihak yang terlibat dalam pelaksanaan penawaran umum obligasi daerah di pasar modal, namun tidak secara langsung dalam proses transaksi perdagangan efek yang terdiri dari penyediaan penguatan kredit, lembaga pemeringkat efek dan penasehat investasi.

\section{Proses Penerbitan Obligasi Daerah}

Sebelum obligasi daerah diterbitkan di pasar modal, ada beberapa tahapan yang dilakukan oleh pemerintah daerah terlebih dahulu. Meliputi persiapan didaerah, persetujuan Menteri Keuangan, tahap pra-regrestrasi dan 
regrestrasi, dan yang terakhir tahap penawaran umum. Tahapan ini diatur dalam Peraturan Menteri Keuangan Nomor 147/PMK.07/2006 dan peraturan Bapepam dan LK yang dijelaskan dalam Bab IV Buku Panduan

\section{Metode Penelitian}

\section{Pendekatan Penelitian (Jenis dan Metode)}

Jenis penelitian yang digunakan dalam penelitian ini adalah penelitian kualitatif dengan menggunakan metode penelitian analisis deskriptif yang dilakukan melalui aktivitas eksplorasi yang dapat menjelaskan masalah-masalah yang menjadi fokus masalah dalam penelitian ini. Metode tersebut digunakan untuk mengetahui permasalahan pada penerbitan obligasi daerah yang tak kujung terbit pada pemerintahan daerah Jawa Tengah, Sumatra Barat, dan Kalimantan Barat. Selain metode analisis diskriptif peneliti juga menggunakan metode analisis SWOT (Strength, Weakness, Opportuniti, Threat) yang digunakan untuk mengkaji kelebihan, kekurangan, peluang dan ancaman dalam penerbitan obligasi daerah yang mana nantinya akan digunakan sebagai alternatif perkembangan daerah dan menentukan strategi yang harus dilakukan oleh pemerintah dalam proses penerbitan obligasi daerah di Provinsi Jawa Tengah, Sumatra Barat, dan Kalimantan Barat.

\section{Sumber data}

Sumber data yang digunakan dalam dalam penelitian ini berasal dari data sekunder yang diperoleh dari data APBD provinsi Jawa Tengah, Sumatra Barat, dan Kalimantan Barat maupun laporan penelitian terdahulu dan website yang dapat menunjang penelitian ini.

\section{Hasil dan Pembahasan \\ Analisis Pendapatan}

Kemandirian keuangan Provinsi di Indonesia khususnya Provinsi Jawa Tengah, Sumatra Barat dan Kalimantan Barat dapat dilihat melalui besarnya PAD yang dibandingkan dengan total pendapatan. Kemandirian Provinsi Jawa Tengah, Sumatra, dan Kalimantan dapat dilihat pada pada pembahasan berikut.

Untuk mendapatkan pinjaman pemerintah daerah harus memiliki kemampuan dalam memenuhi kewajiban yang ditunjukan dengan adanya beberapa persyaratan segi finansial maupun non finansial. Persyaratan kemampuan finansial yaitu adanya jaminan dalam Anggaran Pendapatan Belanja Daerah (APBD) yang ditunjukan dengan pendapatan setiap tahun. APBD tahun anggaran 2019, Pemerintah Provinsi Jawa Tengah merencanakan pendapatan sebesar Rp.25.965.581.322.000,00 dan belanja daerah sebesar Rp.26.632.340.745.000,00 sehingga diperkirakan mengalami defisit sebesar Rp.666.759.423.000,00. Untuk menutup kerugian anggaran Pemerintah Provinsi Jawa Tengah melakukan pembiayaan Daerah sebesar 
Rp.666.759.423.000,00 yang berasal dari Sisa Lebih Pembiayaan Anggaran (SILPA).

Untuk Pemerintah Provinsi Sumatra Barat merencanakan pendapatan sebesar Rp.1.004.996.082.652,00 dan belanja daerah sebesar Rp.1.019.920.621.019,00 sehingga diperkirakan mengalami defisit sebesar Rp.14.924.538.367,00. Untuk menutup kekuarangan anggaran Pemerintah Provinsi di Sumatra Barat melakukan pembiayaan Daerah sebesar Rp. 14.924.538.367,00 berasal dari Sisa Lebih Pembiayaan Anggaran (SILPA).

Selanjutnya pada Pemerintah Kalimantan Barat merencanakan pendapatan sebesar Rp.5.760.665.710.092,00 dan belanja daerah sebesar Rp.5.910.665.710.092,00 sehingga diperkirakan mengalami kekurangan sebanyak Rp.150.000.000.000,00. Untuk menutup kekurangan anggaran Pemerintah Provinsi Jawa Tengah melakukan pembiayaan Daerah sebesar Rp.150.000.000.000,00 berasal dari Sisa Lebih Pembiayaan Anggaran (SILPA). Tabel di bawah ini merupakan APBD Pemeritah Provinsi Jawa Tengah, Sumatra Barat, dan Kalimantan Barat.

\section{Tabel 1}

APBD TAHUN 2019

\begin{tabular}{|c|c|c|c|c|}
\hline $\begin{array}{c}\text { Kode } \\
\text { Rekening }\end{array}$ & Keterangan & Jawa Tengah & Sumatra Barat & $\begin{array}{c}\text { Kalimantan } \\
\text { Barat }\end{array}$ \\
\hline 4 & PENDAPATAN & 25.965.581.322.000 & 1.004.996.082.652 & 5.760 .665 .710 .092 \\
\hline 4.1 & $\begin{array}{l}\text { PENDAPATAN ASLI } \\
\text { DAERAH }\end{array}$ & 14.112.159.378.000 & 90.085 .859 .652 & 2.046.976.954.092 \\
\hline 4.1 .1 & Pendapatan Pajak Daerah & 11.712 .670 .654 .000 & 27.125.755.718 & 1.756.322.680.300 \\
\hline 4.1 .2 & Hasil Retribusi Daerah & 126.080 .182 .000 & 5.185 .665 .000 & 39.184 .694 .000 \\
\hline 4.1 .3 & $\begin{array}{l}\text { Hasil Pengelolaan Kekayaan } \\
\text { Daerah yang Dipisahkan }\end{array}$ & 513.121 .184 .000 & 4.641.438.934 & 87.295 .077 .792 \\
\hline 4.1 .4 & $\begin{array}{l}\text { Lain-lain Pendapatan Asli } \\
\text { Daerah yang Sah }\end{array}$ & 1.760.287.358.000 & 136.741.293.000 & 164.174.502.000 \\
\hline 4.2 & DANA PERIMBANGAN & 11.766.733.523.000 & 778.168 .930 .000 & 3.696.069.297.000 \\
\hline 4.2 .1 & $\begin{array}{l}\text { Bagi Hasil Pajak/Bagi Hasil } \\
\text { Bukan Pajak }\end{array}$ & 786.265 .565 .000 & 22.168 .133 .000 & 227.170 .469 .000 \\
\hline 4.2 .2 & Dana Alokasi Umum & 3.784.512.513.000 & 522.603 .733 .000 & 1.756.069.684.000 \\
\hline 4.2 .3 & Dana Alokasi Khusus & 7.195.955.354.000 & 233.397 .064 .000 & 1.712.829.144.000 \\
\hline 4.3 & $\begin{array}{l}\text { LAIN-LAIN } \\
\text { PENDAPATAN DAERAH } \\
\text { YANG SAH }\end{array}$ & 86.688 .421 .000 & 136.741.293.000 & 17.619 .459 .000 \\
\hline 4.3 .1 & Pendapatan Hibah & 24.300 .000 .000 & 1.500 .000 .000 & 2.348 .000 .000 \\
\hline 4.3 .2 & Dana Insentif Daerah & 62.388 .421 .000 & 97.546 .293 .000 & 62.388 .421 .000 \\
\hline
\end{tabular}




\begin{tabular}{|c|c|c|c|c|}
\hline 5 & BELANJA & 26.632.340.745.000 & 1.019.920.621.019 & 0 \\
\hline 5.1 & Belanja Tidak Langsung & 18.805 .819 .699 .000 & 526.800 .097 .340 & 5.760 .665 .710 .092 \\
\hline 5.2 & Belanja Langsung & 7.826.521.046.000 & 493.120.523.679 & 5.910.665.710.092 \\
\hline & SURPLUS/ DEFISIT & $(666.759 .423 .000)$ & $(14.924 .538 .367)$ & 3.207.622.093.065 \\
\hline 6 & PEMBIAYAAN DAERAH & 666.759 .423 .000 & & 2.703.043.617.026 \\
\hline 6.1 & $\begin{array}{l}\text { PENERIMAAN } \\
\text { PEMBIAYAAN DAERAH }\end{array}$ & 686.759 .423 .000 & 17.424.538.367 & $(150.000 .000 .000)$ \\
\hline 6.1 .1 & $\begin{array}{l}\text { Sisa Lebih Perhitungan } \\
\text { Anggaran Tahun Anggaran } \\
\text { Sebelumnya }\end{array}$ & 686.759 .423 .000 & 17.424.538.367 & \\
\hline 6.2 & $\begin{array}{l}\text { PENGELUARAN } \\
\text { PEMBIAYAAN DAERAH }\end{array}$ & 20.000 .000 .000 & 2.500 .000 .000 & 150.000 .000 .000 \\
\hline 6.2 .2 & $\begin{array}{l}\text { Penyetoran Modal (Investasi) } \\
\text { Pemerintah Daerah }\end{array}$ & 20.000 .000 .000 & 2.500 .000 .000 & 150.000 .000 .000 \\
\hline & PEMBIAYAAN NETTO & 666.759 .423 .000 & 14.924.538.367 & 150.000 .000 .000 \\
\hline 6.3 & $\begin{array}{r}\text { Sisa lebih Pembiayaan } \\
\text { Anggaran Tahun berkenaan } \\
\text { (SILPA) }\end{array}$ & 0 & 0 & 0 \\
\hline
\end{tabular}

https://bpkad.jatengprov.go.id http://bukittinggikota.go.id http://kalbarprov.go.id

Berdasarkan data diatas dan didasari dengan penelitian sebelumnya dapat disimpulkan bahwa Provinsi Jawa Tengah, Sumatra Barat dan Kalimantan Barat secara kondisi finansial dapat menerbitkan obligasi daerah. Tetapi masih banyak juga persyaratan lain yang harus dipenuhi dan kendala yang harus dihadapi oleh Pemerintah Daerah untuk menerbitkan obligasi daerah.

\section{Kendala Penerbitan Obligasi Daerah}

Kebijakan Pemerintah Daerah dalam mengelola obligasi daerah untuk menangani pinjaman diatur oleh Undang-Undang No. 33 tahun 2004. Undang-undang No. 33 tahun 2004 merupakan sumber dasar hukum atau pedoman dalam proses penerbitan obligasi daerah. Peraturan Bapepam yang mengatur obligasi daerah dapat menentukan pemerintah dalam menerbitkan obligasi daerah. Namun Pemerintah Daerah belum memiliki atau belum menerapkan syarat yang ditentukan dalam menerbitkan obligasi daerah.

Faktor yang harus dibenahi untuk proses penerbitan obligasi daerah, yaitu :

1. Penerapakan Standar Akuntansi Keuangan Pemerintah Daerah.

2. Debt Management Unit (DMU) Obligasi Daerah. 
3. SDM Pengelola Debt Management Unit (DMU)

4. Pengetahuan bagi masyarakat tentang obligasi daerah.

5. Menentukan lembaga kredit Rating Agincy (RA)

6. Lembaga yang Menjamin obligasi daerah.

Penerapan standar Akuntansi Keuangan Pemerintah Daerah perlu dipersiapkan secara matang supaya Bapepam dapat menerbitkan persyaratan tersebut. Kegiatan pengelolaan dan administrasi penyelenggaraan pemerintah sudah padat di tambah lagi dengan pengelolaan dan administrasi kegiatan obligasi daerah, tidak memungkinkan secara administrasi. Untuk itu perlu dibentuk suatu badan khusus untuk mengelola kegiatan penerbitan obligasi daerah (Debt Management Unit Obligasi Daerah). Pengelolaan utang (obligasi daerah) tidak ditangani oleh bagian anggaran, melainkan ditangani oleh DMU.

Tugas yang harus diselesaikan oleh DMU yaitu merencanakan kebutuhan biaya, menyusun level utang, mengkaji alternatif pembayaran pokok dan bunga, dan menyiapkan administrasi penerbitan obligasi daerah. Badan yang mengelola utang (obligasi) diperlukan kualifikasi yang profesional dan berpengalaman. Untuk itu SDM pada DMU perlu direkrut dari instansi yang berada pada lingkungan pemerintah atau dari instansi lain yang harus melakukan pendidikan terhadap obligasi daerah. Persiapan SDM yang berkualitas perlu dilakukan pemda dalam melakukan persiapan proses penerbitan obligasi daerah.

Pemerintah dalam persiapan penerbitan obligasi, perlu menentukan suatu lembaga peringkat (Rating Agincy) yang independen untuk menentukan peringkat atas obligasi yang akan diterbitkan. Semakin tinggi obligasi semakin rendah resiko yang dihadapi investor, begitu sebaliknya. Untuk itu pemerintah daerah harus dapat menentukan lembaga peringkat untuk persiapan menentukan obligasi yang akan diterbitkan. Masa berlaku obligasi daerah ditentukan pada perjanjian antara pemerintah daerah dengan wali amanat yang mewakili investor. Namun peran penting sehubungan dengan sukses atau tidaknya penerbitan obligasi daerah dijamin oleh lembaga penjamin (under writing). Lembaga yang membantu emiten dalam proses pendaftaran obligasi di bursa efek merupakan lembaga penjamin. Persiapan under writen sangat diperlukan dalam memenuhi ketentuan peraturan Bapepam.

Kendala dalam proses penerbitan obligasi daerah di berbagai daerah berbeda-beda seperti halnya di Jawa Tengah, Sumatra Barat, dan Kalimantan Barat ketiganya mempunyai kendala yang berbeda dalam penerbitan obligasi daerah. Namun yang menjadi kendala utama dalam penerbitan obligasi daerah yaitu persetujuan atau ijin dari Dewan Perwakilam Rakyat Daerah (DPRD). Supaya obligasi daerah dapat diterbitkan perlu adanya persetujuan dari DPRD setempat. Misalnya di Jawa Tengah segala aspek seperti administrasi dan sumberdaya manusia untuk menerbitkan obligasi daerah sudah terealisasikan, tapi di Jawa Tengah belum bisa menerbitkan obligasi daerah karena belum mendapat persetujuan dari DPRD Jawa tengah. Untuk itu pemerintah daerah 
meminta bantuan OJK untuk menjelaskan secara rinci tentang obligasi daerah supaya DPRD Jateng paham manfaat penerbitan obligasi daerah, dan menjelaskan obligasi daerah kepada DPRD juga merupakan hal yang tidak mudah karena DPRD sendiri lebih mengerti bidang politik daripada ekonomi (Bisnis.com, 2020a).

Kendala penerbitan obligasi daerah tidak hanya persetujuan dari DPRD setempat, seperti di Provinsi Sumatra Barat masih beranggapan bahwa penerbitan obligasi daerah masih sangat rumit dan persyaratan yang harus dipenuhi pemerintah daerah dalam menerbitkan obligasi daerah masih sangat sulit, oleh karena itu pemerintah daerah Provinsi Sumatra Barat belum mempersiapkan penerbitan obligasi daerah secara lebih lanjut lagi(Bisnis.com, 2020c).

Sedangkan di Kalimantan yang menjadi kendala yaitu penerbitan obligasi yang lumayan panjang dan aspek kehati-hatian. Dalam penerbitan daerah tidak hanya dilihat dari administrasi, sumber daya manusia, dan persetujuan DPRD. Namun kelayakan proyek juga perlu diperhatikan karena berpengaruh pada return untuk pengembalian kupon dan pokok obligasi tersebut secara tepat waktu. Kepala daerah Kalimantan juga menuturkan ada beberapa tantangan dalam penerbitan surat utang. Pemerintah daerah harus dapat menyiapkan perangkat peraturan daerah, unit pengelola obligasi daerah dan sumber daya manusia. Selain itu, proyek-proyek yang akan dibiayai harus diyakini akan kelayakan investasinya agar dapat menjamin tingkat pengembalian kepada para investor. Daerah yang akan menerbitkan obligasi harus mampu membuka akses publik terhadap laporan keuangan daerah tersebut, karena keterbukaan keuangan serta informasi menjadi hal yang sangat diperlukan untuk pemberian rating obligasi dari lembaga pemeringkat nantinya(Bisnis.com, 2020b).

Jika ada pemerintah daerah (Pemda) yang akan menerbitkan obligasi daerah, maka didukung OJK secara penuh, untuk itu OJK pasar modal akan terus memberikan dukungan dalam bentuk asistensi atau melakukan presentasi terkait obligasi daerah sehingga informasi-informasi terkait obligasi daerah bisa dipahami secara terperinci oleh pemerintah daerah.

\section{Analisis Obligasi Daerah Sebagai Alternatif Perkembangan Daerah}

Analisis ini digunakan untuk mengetahui kelebihan, kelemahan, peluang dan ancaman dalam penerbitan obligasi daerah sebagai sumber pembiayaan pembangunan di daerah, serta strategi yang perlu digunakan dalam penerbitan obligasi daerah yang digunakan sebagai pembiayaan pembangunan daerah sehingga dapat berjalan dengan optimal. Di bawah ini merupakan hasil dari analisis SWOT penerbitan obligasi daerah sebagai salah satu faktor perkembangan daerah: 
Tabel 2

Hasil Analisis IFAS

\begin{tabular}{|c|c|c|c|c|c|c|c|c|c|c|}
\hline \multirow{2}{*}{$\begin{array}{l}\mathrm{N} \\
\mathrm{O}\end{array}$} & \multirow{2}{*}{ Faktor Strategis } & \multicolumn{3}{|c|}{ Jawa Tengah } & \multicolumn{3}{|c|}{ Sumatra Barat } & \multicolumn{3}{|c|}{ Kalimantan Barat } \\
\hline & & Bobot & Rating & Skor & Bobot & Rating & Skor & Bobot & Rating & Skor \\
\hline \multirow{4}{*}{1} & \multicolumn{10}{|c|}{ Strength } \\
\hline & $\begin{array}{l}\text { Adanya semangat } \\
\text { lebih dari } \\
\text { Pemerintah untuk } \\
\text { membangun } \\
\text { daerah }\end{array}$ & 0,20 & 4 & 0,8 & 0,15 & 2 & 0,3 & 0,15 & 3 & 0,5 \\
\hline & $\begin{array}{l}\text { Masyarakat umum } \\
\text { maupun instansi } \\
\text { memiliki potensi } \\
\text { untuk membeli } \\
\text { obligasi daerah } \\
\text { yang diterbitkan } \\
\text { pemerintah daerah }\end{array}$ & 0,15 & 4 & 0,6 & 0,15 & 3 & 0,5 & 0,15 & 3 & 0,5 \\
\hline & $\begin{array}{l}\text { Jankauan } \\
\text { perbankan lebih } \\
\text { meluas khususnya } \\
\text { di daerah-daerah } \\
\text { yang berpotensi } \\
\text { untuk dapat } \\
\text { dilakukan } \\
\text { penjualan maupun } \\
\text { pembelian obligasi } \\
\text { daerah }\end{array}$ & 0,15 & 4 & 0,6 & 0,20 & 3 & 0,6 & 0,20 & 3 & 0,6 \\
\hline & \multicolumn{10}{|c|}{ Weakness } \\
\hline 2 & $\begin{array}{l}\text { Obligasi daerah } \\
\text { yang diterbitkan } \\
\text { oleh pemerintah } \\
\text { daerah hanya dapat } \\
\text { mendanai kegiatan } \\
\text { investasi sektor } \\
\text { publik }\end{array}$ & 0,15 & 4 & 0,6 & 0,10 & 4 & 0,4 & 0,10 & 4 & 0,4 \\
\hline & $\begin{array}{l}\text { Kurangnya } \\
\text { pengalaman terkait } \\
\text { obligasi daerah }\end{array}$ & 0,10 & 3 & 0,3 & 0,15 & 4 & 0,6 & 0,15 & 4 & 0,6 \\
\hline & $\begin{array}{l}\text { Kepala daerah dan } \\
\text { DPRD hanya } \\
\text { memiliki masa }\end{array}$ & 0,15 & 4 & 0,6 & 0,15 & 4 & 0,6 & 0,15 & 4 & 0,6 \\
\hline
\end{tabular}




\begin{tabular}{|c|c|c|c|c|c|c|c|c|c|}
\hline $\begin{array}{l}\text { jabatan selama } 5 \\
\text { tahun, sehingga } \\
\text { dikhawatirkan } \\
\text { dapat mengham } \\
\text { pembangunan } \\
\text { proyek yang } \\
\text { dilakukan melalı } \\
\text { dana obligasi } \\
\text { karena adanya } \\
\text { pergantian jabat } \\
\text { setiap } 5 \text { tahun } \\
\text { sekali }\end{array}$ & & & & & & & & & \\
\hline $\begin{array}{l}\text { Nilai nominal } \\
\text { obligasi daerah } \\
\text { yang masih tings } \\
\text { sehingga sulit } \\
\text { dijangkau oleh } \\
\text { masyarakat }\end{array}$ & 0,10 & 4 & 0,4 & 0,10 & 4 & 0,4 & 0,10 & 4 & 0,4 \\
\hline Total & 1,00 & & 3,9 & 1,00 & & 3,4 & 1,00 & & 3,5 \\
\hline
\end{tabular}

Tabel 3

Hasil Analisis EFAS

\begin{tabular}{|c|c|c|c|c|c|c|c|c|c|c|}
\hline \multirow{2}{*}{ No } & \multirow{2}{*}{ Faktor Strategis } & \multicolumn{3}{|c|}{ Jawa Tengah } & \multicolumn{3}{|c|}{ Sumatra Barat } & \multicolumn{3}{|c|}{ Kalimantan Barat } \\
\hline & & Bobot & Rating & Skor & Bobot & Rating & Skor & Bobot & Rating & Skor \\
\hline & \multicolumn{10}{|c|}{ Opportunities } \\
\hline 1 & $\begin{array}{l}\text { UU Keungan } \\
\text { Negara } \\
\text { memberikan } \\
\text { peluang kepada } \\
\text { Pemda untuk } \\
\text { mendapatkan } \\
\text { pendanaan } \\
\text { tambahan selain } \\
\text { dari pemerintah } \\
\text { pusa dan } \\
\text { Pendapatan Asli } \\
\text { Daerah (PAD) }\end{array}$ & 0,15 & 4 & 0,6 & 0,20 & 4 & 0,8 & 0,15 & 4 & 0,6 \\
\hline & $\begin{array}{l}\text { Adanya proyek } \\
\text { yang didanai } \\
\text { melalui obligasi } \\
\text { daerah berpeluang } \\
\text { untuk }\end{array}$ & 0,20 & 4 & 0,8 & 0,15 & 4 & 0,6 & 0,15 & 4 & 0,6 \\
\hline
\end{tabular}




\begin{tabular}{|c|c|c|c|c|c|c|c|c|c|c|}
\hline & $\begin{array}{l}\text { mempercepat } \\
\text { pertumbuhan } \\
\text { ekonomi di suatu } \\
\text { daerah }\end{array}$ & & & & & & & & & \\
\hline & $\begin{array}{l}\text { Bunga yang } \\
\text { diperoleh dari } \\
\text { obligasi daerah } \\
\text { dapat dinikmati } \\
\text { oleh masyarakat } \\
\text { maupun instansi } \\
\text { yang membeli } \\
\text { obligasi daerah } \\
\text { sehingga dapat } \\
\text { meningkatkan } \\
\text { perputaran } \\
\text { perekonomian } \\
\text { daerah }\end{array}$ & 0,15 & 4 & 0,6 & 0,15 & 4 & 0,6 & 0,20 & 4 & 0,8 \\
\hline \multirow{5}{*}{2} & \multicolumn{10}{|c|}{ Threat } \\
\hline & $\begin{array}{l}\text { Meningkatnya } \\
\text { jumlah utang } \\
\text { pemerintah, yang } \\
\text { mengakibatkan } \\
\text { country risk } \\
\text { meningkat }\end{array}$ & 0,20 & 2 & 0,4 & 0,20 & 3 & 0,6 & 0,20 & 3 & 0,6 \\
\hline & $\begin{array}{l}\text { Adanya resiko } \\
\text { moral bagi pejabat } \\
\text { daerah yaitu } \\
\text { menikmati hasil } \\
\text { pinjaman dan } \\
\text { memberikan } \\
\text { tanggungjawab } \\
\text { utang kepada } \\
\text { pimpinan } \\
\text { selanjutnya }\end{array}$ & 0,15 & 2 & 0,3 & 0,15 & 3 & 0,5 & 0,15 & 3 & 0,5 \\
\hline & $\begin{array}{l}\text { Penerbitan obligasi } \\
\text { daerah } \\
\text { menimbulkan } \\
\text { kesenjangan antar } \\
\text { daerah }\end{array}$ & 0,15 & 2 & 0,3 & 0,15 & 3 & 0,5 & 0,15 & 3 & 0,5 \\
\hline & Total & 1,00 & & 3,0 & 1,00 & & 3,5 & & & 3,5 \\
\hline
\end{tabular}


Berdasarkan hasil dari Tabel 2 dan 3 matriks IFAS dan EFAS. Hasil tersebut kemudian disajikan ke dalam tabel matriks internal dan eksternal seperti yang disajikan pada Tabel 4.

Tabel 4

Skor IFAS dan EFAS

\begin{tabular}{|c|c|c|c|c|c|}
\hline \multirow{2}{*}{ No } & \multirow{2}{*}{ Provinsi } & \multicolumn{2}{|c|}{ IFAS } & \multicolumn{2}{|c|}{ EFAS } \\
\hline & & Kategori & Skor & Kategori & Skor \\
\hline \multirow{3}{*}{1} & \multirow{3}{*}{ Jawa Tengah } & Kekuatan (S) & 2,0 & Peluang $(\mathrm{O})$ & 2,0 \\
\hline & & Kelemahan (W) & 1,9 & Ancaman $(\mathrm{T})$ & 1,0 \\
\hline & & Total (S-W) & 0,1 & Total (O-T) & 1,0 \\
\hline \multirow{3}{*}{2} & \multirow{3}{*}{$\begin{array}{l}\text { Sumatra } \\
\text { Barat }\end{array}$} & Kekuatan (S) & 1,4 & Peluang (O) & 2,0 \\
\hline & & Kelemahan (W) & 2,0 & Ancaman $(\mathrm{T})$ & 1,5 \\
\hline & & Total (S-W) & $-0,6$ & Total (O-T) & 0,5 \\
\hline \multirow{3}{*}{3} & \multirow{3}{*}{$\begin{array}{c}\text { Kalimantan } \\
\text { Barat }\end{array}$} & Kekuatan (S) & 1,5 & Peluang $(\mathrm{O})$ & 2,0 \\
\hline & & Kelemahan (W) & 2,0 & $\begin{array}{l}\text { Ancaman } \\
(\mathrm{T})\end{array}$ & 1,5 \\
\hline & & Total (S-W) & $-0,5$ & Total (O-T) & 0,5 \\
\hline
\end{tabular}

Selanjutnya hasil analisis di atas akan menunjukan berada pada posisi mana kondisi penerbitan obligasi di Jawa Tengah, Sumatra Barat, dan Kalimantan Barat, apakah pada kuadran I (Strength Opportunity), Kuadran II (Strength Threat), Kuadran III (Weakness Opportunity), atau Kuadran IV (Weakness Threat). Kemudian Hasil IFAS dan EFAS disajikan kedalam Grafik kuadran SWOT, Titik pada sumbu X menunjukan IFAS sedangkan sumbu $\mathrm{Y}$ menunjukan EFAS. Kemudian ditarik garis pertemuan keduanya. 


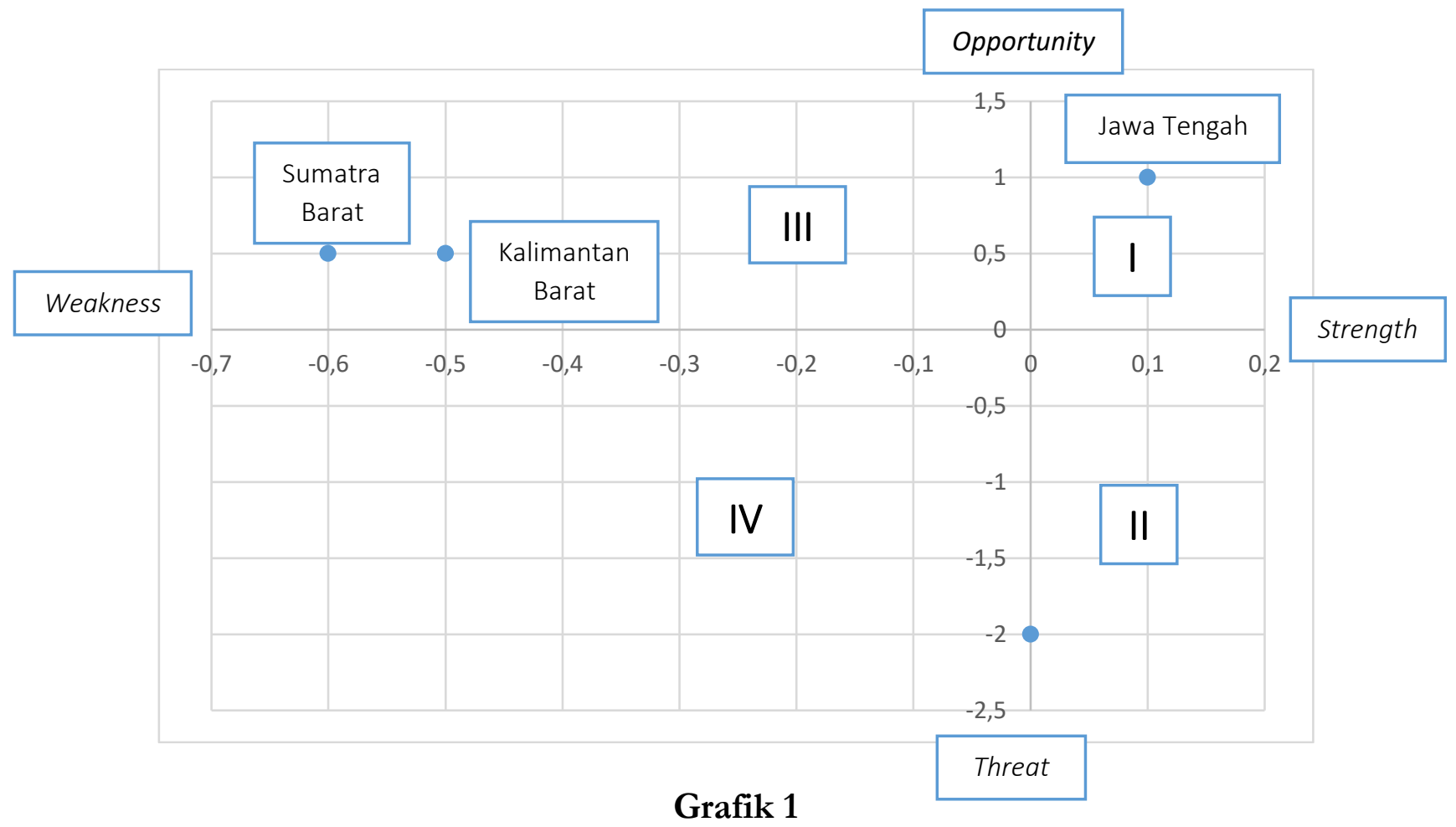

Berdasarkan Grafik 1 diketahui kuadran hasil perhitungan IFAS dan EFAS yaitu:

1. Jawa Tengah berada pada Kuadran I (Strength Opportunity)

2. Sumatra Barat berada pada kuadran III (Weakness Opportunity)

3. Kalimantan Barat sama dengan Sumatra Barat berada di kuadran III (Weakness Opportunity)

Berdasarkan analisis SWOT dan hambatan yang mungkin timbul dalam proses penerbitan obligasi daerah, maka strategi yang harus digunakan dalam proses penerbitan obligasi daerah sebagai salah satu faktor perkembangan daerah yaitu:

1. Jawa Tengah

Pada posisi kuadran I (positif, positif) menunjukan bahwa penerbitan obligasi daerah di Provinsi Jawa Tengah sangat kuat karena terdapat kekuatan yang dapat dimanfaatkan untuk mencapai peluang yang menguntungkan. Oleh sebab itu, strategi alternatif yang dapat digunakan oleh pemda Jawa Tengah dalam melakukan penerbitan obligasi daerah yaitu dengan menggunakan strategi pengembangan (strategi progresif) yang berarti pemerintah daerah Jawa Tengah berada dalam kondisi keorganisasian yang baik dan bagus. Sehingga pemda Jawa Tengah benar-benar dimungkinkan untuk terus menjalankan ekspansi, memaksimalkan penerbitan obligasi daerah dan meraih kemajuan secara maksimal. 
2. Sumatra Barat

Pada posisi kuadran III (negatif, positif) menunjukan bahwa penerbitan obligasi daerah di Provinsi Sumatra Barat masih mengalami kelemahan difaktor internalnya, sehingga peluang dalam menerbitkan obligasi daerah masih sulit dicapai. Untuk itu pemerintah daerah Sumatra Barat harus memiliki tiga strategi alternatif agar dapat menerbitkan obligasi daerah, yaitu dengan menggunakan strategi konsolidasi perbaikan, mengubah cara pandang dalam hal penerbitan obligasi daerah, dan harus dapat menghilangkan penyebab masalah dalam penerbitan obligasi daerah agar nantinya ancaman yang mengancam penerbitan obligasi daerah dapat dihindari. Selain tiga strategi tersebut, pemerintah daerah Sumatra Barat juga bisa merubah strategi sebelumnya yang telah dilakukan, karena dikwatirkan cara yang lama tersebut sulit untuk menangkap peluang dalam penerbitan obligasi daerah yang ada.

3. Kalimantan Barat

Provinsi Kalimantan Barat berada diposisi yang sama dengan Provinsi Sumatra barat yaitu di posisi kuadran III (negatif, positif) yang berarti pemerintah daerah Kalimantan Barat berada dalam keorganisasian yang lemah namun sungguh-sungguh berpeluang, oleh karena adanya peluang itu pemerintah Kalimantan Barat perlu melakukan "ubah taktik" atau mengubah strategi sebelumnya agar dapat menerbitkan obligasi daerah.

\section{Kesimpulan}

Dari penelitian diatas dapat ditarik kesimpulan bahwa penerbitan obligasi daerah menjadi salah satu alternatif yang layak dipertimbangkan sebagai sumber pendanaan bagi pemda guna meningkatkan pembangunan daerah. Obligasi daerah merupakan peluang yang besar untuk meningkatkan pembangunan daerah dibanding dengan sumber pendanaan yang lain, oleh karena itu dalam penerbitan obligasi daerah pemerintah daerah juga harus mempersiapkan diri secara matang untuk mejual obligasi daerah tersebut. Pemda harus mengkai aspek finansial dan teknisnya, harus melihat urgensi dari penjualan obligasi daerah tersebut, dan juga perlu dikaji lebih mendalam lagi apakah daerah tersebut benar-benar kekurangan dana untuk memenuhi anggaran pengeluarannya dan mampu membayar kembali nantinya saat jatuh tempo. Hal tersebut perlu dilakukan agar daerah tidak asal memanfaatkan semua peluang pinjaman yang ada.

Penerbitan obligasi daerah dapat membuka peluang masyarakat daerah untuk ikut serta dalam hal investasi. Berdasarkan analisis diatas beberapa daerah yang dijadikan objek penelitian (Jawa Tengah, Sumatra Barat, dan Kalimantan Barat) memiliki posisi yang berbeda-beda dalam usaha penerbitan obligasi daerah. Dimana Jawa Tengah berada diposisi teratas dengan Kuadran I karena Jawa Tengah sudah memiliki strategi dan rencana yang matang dalam 
penerbitan obligasi daerah. Sedangkan Sumatra Barat dan Kalimantan Barat masih berada di Kuadran ke-III dikarenakan belum optimalnya perencanaan penerbitan obligasi daerah didaerah tersebut. Meskipun demikian ketiganya sudah memiliki tingkat finansial yang memadai jika akan melakukan penerbitan obligasi daerah, tinggal dilakukan pengoptimalan lebih lanjut lagi terhadap syarat-syarat yang harus ditempuh untuk dapat menerbitkan obligasi daerah. Strategi yang dapat dilakukan pemerintah dalam upaya penerbitan obligasi daerah yaitu dengan memanfaatkan semangat membangun daerah serta potensi masyarakat daerah yang bersedia untuk membantu pembangunan daerah melalui penerbitan obligasi daerah, mengikut sertakan masyarakat dalam pengawasan proyek untuk meminimalisir kemungkinan terjadinya moral bazard oleh pejabat daerah, perlu disiapkan struktur dan infrastruktur yang mendukung penerbitan obligasi daerah, dan akan lebih baik jika laporan obligasi daerah terkait pinjaman daerah tersebut disertakan akuntabilitas publiknya sejak dari proses awal perencanaan sampai pemanfaatan dan pelunasan. Hal tersebut harus dibuat transparan dan terbuka terhadap kontrol dari masyarakat luas agar dapat meminimalisir kemungkinan negatif yang akan terjadi. 


\section{DAFTAR PUSTAKA}

Ambarwati, D. I., Hamid, E. S., \& Suprihanto, J. (2016). Kelayakan Pembiayaan Obligasi Daerah untuk Pembangunan Proyek Bus Rapid Trans (BRT) Guna Menunjang Ketahanan Ekonomi Daerah (Studi Pada Pemerintah Provinsi Sulawesi Selatan). Jurnal Ketahanan Nasional, 22(3), 267-284.

Bisnis.com. (2020a). Obligasi Daerh Jateng tak. Kunjung Terealisasi, Terganjal Restu DPRD.

Bisnis.com. (2020b). OJK Kaltim: Proses Penerbitan Obligasi Daerah Lumayan Panjang.

Bisnis.com. (2020c). Pemda Sulit Penubi Langkah Penerbitan Obligasi Daerah.

Empresas, R. de A. de. (2012). A Brazilian Municipal Bond Market: Theory, Repression and Prospects.

Feng, X. (2013). Local Government Debt and Municipal Bonds in China: Problems and a Framework of Rules. The Copenhagen Journal of Asian Studies, 31(2), 23-53.

Hamid, E. S. (2003). Prospek Obligasi Daerah sebagai Alternatif Pembiayaan Pembangunan. 6(1), 21-29.

Kementerian Keuangan. (n.d.). PP Nomor 107 Tahun 2000 tentang Pinjaman Derah.

News, A. (2019). OJK Sebut Kendala Pemda dalam Penerbitan Obligasi Daerah.

Okta, D., \& Kaluge, D. (2011). Analisis Peluang Penerbitan Obligasi Daerah sebagai Alternatif Pembiayaan Daerah. Journal of Indonesia Applied Economics, 5, 157-171.

Resen, M. gde subha karma. (2015). Aspek Yuridis Penerbitan Obligasi Daerah sebagai Sumber Pembiayaan Alternatif Daerah. 1.

Setiadi, W. (n.d.). Kajian Obligasi Daerah sebagai Alternatif Sumber Pembiayaan untuk Pembangunan Daerah (Studi Kasus Di Pemerintah Propinsi Jawa Tengah). 61-74.

Sriyono. (2013). Model Pembiayaan Daerah yang Bersumber dari Anggaran Non APBN untuk Meningkatkan Ekonomi Kreatif. Seminar Nasional, 105, 29-30.

Surachman, E. N., \& Setiawan, H. (2016). Municipal Bonds as The Financing Strategy For Urban Infrastructure: Case Study Of Jakarta MRT. Jurnal Keuangan Dan Perbankan, 20(3), 369-381.

Yulianti, A. D. (2018). Strategi Penerbitan Obligasi Daerah Sebagai Alternatif Sumber Penerimaan Daerah di Provinsi Jawa Tengah. 7(3), 268-275. 